\title{
Semiotika Pantun Minang pada Masyarakat Minangkabau Kota Bengkulu
}

\author{
Dina Putri Juni Astuti ${ }^{1 凶}$ \\ Institut Agama Islam Negeri (IAIN) Bengkulu \\ dinaputri@iainbengkulu.ac.id
}

\begin{abstract}
Semiotics as a method of research analysis examines signs, is very interesting to be analyzed in the form of literary oral literature. The use of this method aims to describe the analysis of the Minang pantun semiotic text in the Minnagkabau City of Bengkulu. The research method used is a qualitative descriptive method with a semiotic approach. The data source of this research is the Minang community who uses the Minang pantun with the research data is the Minun pantun text which amounts to 32 Pantun obtained from formal and non-formal activities. The results of this study indicate that: Icon markings are more often used on noun diction by placing them in the first and second rows of the Minang pantun. While the index mark is marked with all life activities in which the Minang pantun often appears in the second or third row of Minang pantun. And the symbolic sign has an explicit and implicit meaning in the pantun, which is often located in the contents of the pantun, or in the third and fourth rows of the Minang pantun. Thus, the semiotics in the Minang pantun are contained in every element of the word play in the Minangkabau Community Minangkabau diction.
\end{abstract}

Keywords: semiotics, pantun minang, minangkabau society, and bengkulu city

Abstrak:Semiotika sebagai salah satu metode analisis penelitian mengkaji tentang tanda, sangat menarik untuk di analisis pada sastra lisan berupa pantun. Penggunaan metode ini bertujuan untuk mendeskripsikan analisis teks semiotika pantun Minang pada masyarakat Minnagkabau Kota bengkulu. Metode penelitian yang digunakan adalah metode deskriptif kualitatif dengan pendekatan semiotik. Sumber data penelitian ini adalah masyarakat Minang yang menggunakan pantun Minang dengan data penelitian adalah teks pantun Minang berjumlah 32 Pantun yang diperoleh dari kegiatan formal dan nonformal. Hasil penelitian ini menunjukkan bahwa: Tanda Ikon lebih sering digunakan pada diksi kata benda dengan penempatannya berada di baris pertama dan kedua pantun Minang. Sedangkan tanda indeks ditandai dengan semua aktifitas kehidupan yang mana pada pantun Minang seringkali muncul di baris kedua atau ketiga pantun Minang. Serta tanda simbol memiliki makna tersurat dan tersirat di dalam pantun yang letaknya sering kali berada di isi pantun, atau pada baris ketiga dan keempat pantun Minang. Dengan demikian, semiotika pada pantun Minang terdapat disetiap unsur permainan kata pada diksi pantun Minang Masyarakat Minangkabau Kota Bengkulu.

Kata kunci: semiotika, pantun minang, masyarakat minangkabau, dan kota bengkulu.

Sitasi Jurnal:

Astuti, D. (2020). Semiotika Pantun Minang pada Masyarakat Minangkabau Kota Bengkulu. Disastra: Jurnal Pendidikan Bahasa dan Sastra Indonesia, 2(1), 43-49. doi:http://dx.doi.org/10.29300/disastra.v2i1.2708 


\section{Pendahuluan}

Negara Indonesia kaya akan keberagaman budaya. Keanekaragaman budaya nusantara yang dimiliki oleh negara Indonesia salah satunya adalah sastra lisan. Contohnya seperti: bahasa rakyat, ungkapan tradisional, pertanyaan tradisional, sajak, puisi rakyat (mite, legenda, dongeng), nyanyian rakyat, permainan rakyat, dan juga makanan rakyat.

Indonesia sebagai masyarakat heterogen memiliki sastra lisan yang berbeda-beda antara satu dengan yang lain, baik perbedaan sastra lisan secara keseluruhan maupun secara dialeknya saja. Perbedaan ini tentunya merupakan sebuah kekayaan yang mencirikan kebudayaan kelompok masyarakat yang bersangkutan.

Di daerah Bengkulu dengan luas wilayah 151,7 $\mathrm{km}^{2}$ dan berpenduduk sebanyak kurang lebih 308.756 jiwa dengan kepadatan $1.838 / \mathrm{km}^{2}$, terdiri atas etnik masyarakat asli hingga ke etnik masyarakat pendatang. Menurut Badan Pusat Statistik Bengkulu suku bangsa yang menetap di daerah kota Bengkulu terdiri atas etnik asli: suku Melayu Bengkulu 15\% dari jumlah penduduk, suku Serawai 15\%, suku Rejang 7\%, suku Lembak 4\% dan suku Melayu Pasemah 2\%. Sedangkan etnik pendatang yaitu: suku Jawa 14\%, suku Minangkabau $12 \%$, suku Sunda Priangan 2\% dan suku lainnya 29\%. Dengan demikian, suku Minangkabau merupakan suku pendatang yang mayoritas penduduk dari Kota Bengkulu. Masyarakat Minangkabau sangat kaya dengan jenis sastra daerah yang diturunkan secara turun-temurun. Sastra daerah ini merupakan bagian dari adat dan budaya Minang itu sendiri. Salah satunya adalah tradisi berpantun.

Tradisi lisan yang cukup populer di lingkungan masyarakat Minangkabau adalah tradisi berpantun. Berpantun bagi masyarakat Minangkabau merupakan alat penyuara kehidupan masyarakat Minang, ketika berpantun seseorang akan mengungkapkan maksud tujuannya tanpa harus mengatakan secara gamblang tentang apa yang ingin diucapkannya. Tradisi berpantun bagi masyarakat Minangkabau dapat melebur diberbagai kalangan, generasi ataupun tingkatan masyarakat, sebagai suatu identitas yang selalu dinyatakan dalam acara-acara adat maupun acara khusus lainnya, baik formal ataupun nonformal.

Hasjim (2001:23) menyatakan bahwa pantun merupakan sebagian dari kebudayaan masyarakat lama, yang bersifat anonim. Hal ini dikarenakan masyarakat lampau memiliki sifat kolektif dan cenderung statis. Sehingga menimbulkan suatu pandangan bahwa segala sesuatu merupakan karya bersama dan milik bersama. Sejalan dengan pendapat Trianto (2004:40), pantun adalah suatu bentuk puisi dengan ucapan yang teratur sebagai sarana mendidik sambil menghibur orang dengan permainan bunyi bahasa seseorang yang memiliki gaya tersendiri dalam mengungkapkan sesuatu. Dengan demikian pantun Minang merupakan seni kebudayaan berupa puisi yang memiliki substansi yang tepat sebagai alat komunikasi yang cerdas dalam permainan berbahasa secara spontanitas dengan mengaktualisasikan realitas kehidupan.

Dalam kegiatan berpantun terdapat tanda-tanda yang harus dipelajari. Tanda- 
tanda tersebut dikaji dengan metode semiotik sebagai bentuk analisis teks yang memiliki hubungan tanda dengan tanda yang mengiringi teks tersebut. Selain itu, metode ini menganalisis secara komprehensif mengenai tanda-tanda yang memaknai aktivitas sosial budaya dalam sebuah wacana. Artinya metode ini juga menganalisis tentang apa yang terjadi di sekitar kita sebagai bentuk gejala sosial budaya.

Istilah semiotik dalam bahasa Yunani adalah kata semeion yang berarti tanda (Endraswara, 2008:64). Selain itu beberapa definisi yang dinyatakan oleh beberapa pakar, diantaranya Sobur (2006:14) mendefinisikan semiotik adalah suatu ilmu atau metode analisis untuk mengkaji tanda. Endraswara (2008:63) menjelaskan bahwa semiotik merupakan ilmu yang mempelajari tanda-tanda dalam karya sastra. Sedangkan Zoest (1991:8) berpendapat bahwa semiotik merupakan kajian teks yang dianggap sebagai suatu tanda yang berbentuk dari sejumlah tanda lain yang merujuk pada suatu kenyataan (denotatum). Dengan demikian, semiotik merupakan metode analisis teks yang memiliki hubungan tanda dengan tanda yang mengiringi teks tersebut.

Pierce dalam (Zaimar, 2008:5-6) membedakan tiga jenis tanda berdasarkan hubungan antara objek dengan yang ditandakan:

1. Ikon ialah hubungan yang berdasarkan kemiripan dengan objek yang mewakilinya. Ikon terdiri atas tiga macam, yaitu ikon topologis, ikon diagramatik, dan ikon metaforis. a. Ikon Topologis adalah hubungan yang berdasarkan kemiripan bentuk, seperti peta dan lukisan realis.

b. Ikon Diagramatik adalah hubungan berdasarkan kemiripan tahapan, seperi diagram. Contohnya: hubungan antara tanda-tanda pangkat militer dengan kedudukan kemiliteran yang diwakili tanda-tanda pangkat itu.

c. Ikon Metaforis adalah hubungan yang berdasarkan kemiripan meskipun hanya sebagian yang mirip, seperti bunga mawar dan gadis dianggap mempunyai kemiripan (kecantikan, kesegaran).

2. Indeks ialah hubungan yang mempunyai jangkauan eksistensial. Contohnya: dalam kehidupan sehari-hari, belaian (kedekatan) dapat mengandung arti banyak. Tingkah laku manusia juga merupakan indeks dari sifat-sifatnya. Asap yang merupakan indeks adanya api, panah menunjukkan jalan yang merupakan indeks arah.

3. Simbol (lambang) ialah tanda yang memiliki hubungan makna dengan yang ditandakan dan bersifat arbitrer, sesuai dengan konvensi suatu lingkungan sosial tertentu. Contohnya: bendera putih sebagai simbol adanya kematian.

Dengan demikian, tradisi berpantun Minang pada masyarakat Minangkabau Kota Bengkulu menggunakan bahasa yang khas. Kekhasan itu dapat dilihat dari ikon, indeks, dan simbol dari teks pantun. Dengan menggunakan analisis semiotik ini dimungkinkan untuk mendeskripsikan makna tanda-tanda semiotik dalam pantun Minang pada masyarakat Minangkabau dan juga mendeskripsikan makna pantun Minang tersebut. 


\section{Metode Penelitian}

Penelitian ini menggunakan metode penelitian deskriptif kualitatif dengan pendekatan semiotika. Metode penelitian deskriptif kualitatif merupakan prosedur penelitian yang dianalisis dengan melihat keadaan objek yang sebenarnya (Eliya, 2018). Adapun tujuan dari penelitian ini adalah untuk mendeskripsikan semiotika pantun Minang yang dilihat berdasarkan tanda ikon, indeks, dan simbol yang digunakan pada pantun Minang. Metode pengumpulan data yang digunakan dalam penelitian ini adalah observasi, wawancara, rekaman, dan catat tulis. Berdasarkan metode pengumpulan data tersebut, teknik digunakan adalah teknik rekam dan teknik catat tulis. Teknik ini dilakukan dengan merekam kegiatan tradisi pantun Minang yang dibantu dengan alat perekam yang ada di gawai. Selanjutnya melakukan teknik memcatat semua data yang diperoleh melalui perekaman dalam bentuk teks tertulis.

Tahap analisis data dilakukan setelah semua data terkumpul. Data yang terkumpul diklasifikasikan berdasarkan permasalahannya. Pertama, mentranskripkan rekaman data dengan memindahkan data dalam bentuk tulisan bahasa Minang ke dalam bentuk bahasa Indonesia. Kedua, mengklasifikasikan data yang terkumpul sesuai dengan tanda semiotika yakni ikon, indeks dan simbol. Ketiga, menganalisis data yang terkumpul berdasarkan semiotika pantun Minang.

\section{Hasil dan Pembahasan}

Keberadaan pantun Minang pada masyarakat Minangkabau sekarang ini masih tetap terjaga dengan baik. Hal ini dikarenakan, pantun Minang memiliki banyak makna tersurat maupun tersirat. Di Kota Bengkulu khususnya, pantun Minang masih bisa dijumpai pada kegiatan formal ataupun nonformal. Pada penelitian ini, Pantun Minang dijumpai pada kegiatan Pengukuhan Pelantikan Ikatan Kepengurusan Keluarga Minang dan Acara Pernikahan dari Masyarakat yang tinggal di Kota Bengkulu.

Dari kegiatan yang telah diikuti maka ditemukan 32 pantun Minang yang digunakan oleh mayarakat Minangkabau. Ketiga puluh dua pantun Minang ini diambil dari tiga macam seni sastra lisan, yakni pidato, tarian, dan persembahan Minangkabau. Dari ketiga puluh dua pantun Minang ini dapat dianalisis berdasarkan semiotika pantun Minang (ikon, indeks dan simbol).

$\begin{array}{ccc}\text { Dalam pantun Minang } & \text { pada } \\ \text { Masyarakat Minangkabau di } & \text { Kota }\end{array}$ Bengkulu ini diperoleh penggunaan tanda semiotika berupa ikon, indeks, dan simbol yakni sebagai berikut.:

Pantun Pertama

Sairiang balam jo barabah

Tabang malayok ka dalam padi

Sairiang salam jo sambah

Salam paarek silaturahmi (I/I.C/A.IKAS)

Terjemahan

Burung Balam dan Berabah yang terbang beriringan

Terbang menutupi hamparan padi

Seiring salam dan sembah

Salam pererat tali silaturahmi

\section{Tanda Ikon}

Pada pantun tersebut terdapat tanda ikon pada penggunaan kata benda, yaitu 
pada kata "balam, barabah, dan padi". Balam dan berabah merupakan sejenis nama burung yang dijadikan ikon dalam pantun tersebut. Begitu juga padi merupakan tanaman yang menghasilkan beras. Ketiga kata tersebut dijadikan ikon dalam penggunaan penyusunan pantun Minang. Dengan demikian, tanda ikon ini berada di baris pertama dan kedua pantun Minang.

\section{Tanda Indeks}

Pada pantun tersebut terdapat tanda indeks, yaitu terdapat pada kalimat "Tabang malayok ka dalam padi" terjemahannya adalah terbang menutupi hamparan padi. Terdapat aktifitas burung balam dan berabah yang terbang menutupi hamparan padi merupakan tanda indeks yang berupa kegiatan aktifitas dari burung. Kalimat tersebut juga berperan dalam pembentukan pantun Minang. Dengan demikian, tanda indeks ini berada di baris kedua pantun Minang.

\section{Tanda Simbol}

Penggunaan tanda simbol yang terdapat pada pantun tersebut adalah kalimat "Sairiang salam jo sambah dan Salam paarek silaturahmi". Makna kalimat tersebut merupakan simbol semboyan yang harus kita ingat dan pelajari. Setiap ada pengucapan salam merupakan tanda untuk mempererat tali silaturahmi antarsesama manusia. Dengan demikian, tanda simbol ini berada di baris ketiga dan keempat pantun Minang.

Secara keseluruhan, makna pantun Minang yang terkandung di dalam pantun tersebut adalah menggambarkan adat sopan santun atau etika dalam pergaulan masyarakat Minang yang mengatur interaksi dan hubungan antar sesama masyarakat lain atau anggota masyarakat Minangkabau itu sendiri. Adat sopan santun ini terdiri atas tiga bagian yang terus-menerus digunakan dalam keseharian masyarakat Minang, yaitu disebut dengan tiga adat "nan sajoli" pertama sembah menyembah, kedua dirih dan pinang, dan ketiga baso dan basiyang memiliki arti sebelum menulai perkataan terlebih dahulu melakukan persembahan kata sebagai bentuk penghormatan kepada orang yang sedang dihadapi. Sirih dan pinang dilambangkan sebagai bentuk formalitas dalam berinteraksi komunikasi adat masyarakat Minangkabau. Sedangkan baso dan basi artinya sebagai bentuk menjaga silaturahmi dalam berbicara. Dengan demikian, adat dari pantun Minang ini diharapkan akan menjaga hubungan baik seseorang terhadap orang disekitarnya sekaligus mempererat tali persaudaraan dan silaturahmi antarsesama selaku.

Pantun kedua:

Jikok dunsanak pai ka lapau

Dibali baranak tali dipanjang batali-tali

Jikok sanak ingin di rantau

Pimpinan usah bagonta-ganti (2/I.C/A.IKAS)

Terjemahan

Jika saudara pergi ke warung

Dibeli berabak tali dipanjangkan menjadi tali yang panjang

Jika saudara ingin pergi ke perantauan

Pimpinan tidak usah bergontaganti 


\section{Tanda Ikon}

Pada pantun tersebut terdapat tanda ikon pada penggunaan kata benda, yaitu pada kata "dunsanak, lapau, tali, dan rantau". Dunsanak terjemahannya adalah saudara sekalian, sedangkan lapau terjemahannya adalah warung. Saudara sekalian merupakan panggilan untuk menyatakan orang Minang secara keseluruhan, dan warung merupakan tempat untuk melakukan aktifitas transaksi jual beli. Sedangkan kata tali merupakan sebuah kata benda yang berbentuk panjang dan sering digunakan untuk mengikat sesuatu. Serta kata rantau merupakan tempat transmigrasi seseorang dari tanah kelahiran yang bertujuan untuk mencari rezeki. Keempat kata tersebut dijadikan ikon dalam penggunaan penyusunan pantun Minang. Dengan demikian, tanda ikon ini berada di baris pertama, kedua dan ketiga pantun Minang.

\section{Tanda Indeks}

Pada pantun tersebut terdapat tanda indeks, yaitu terdapat pada kalimat "Dibali baranak tali dipanjang batali-tali" terjemahannya adalah dibeli beranak tali dipanjangkan sehingga menjadi tali yang panjang dan terlilit. Pada kutipan tersebut terdapat aktifitas membeli tali yang sangat panjang di warung. Kegiatan ini menunjukkan tanda indeks yang memiliki peran dalam pembentukan pantun Minang. Dengan demikian, tanda indeks ini berada di baris kedua pantun Minang.

\section{Tanda Simbol}

Pada pantun tersebut penggunaan tanda simbol yang terdapat pada kalimat "Pimpinan usah bagonta-ganti". Makna kalimat tersebut merupakan simbol semboyan yang harus kita ingat dan pelajari. Apabila saudara Masyarakat Minang yang tinggal di perantauan hendaknya memilih pemimpin itu tidak perlu diganti-ganti jika sudah sesuai dengan visi dan misi yang diyakini. Dengan demikian, tanda simbol ini berada di baris keempat pantun Minang.

Secara keseluruhan makna pantun Minang yang terkandung di dalam pantun tersebut adalah berupa nasihat yang diberikan kepada seorang saudara yang ingin pergi merantau, agar diperantauan nanti mencari saudara yang juga berasal dari tanah kelahiran yang sama. Sehingga saudara lama-kelamaan menjadi sebuah keluarga besar. Apabila orang Minang terpilih menjadi seorang pemimpin di daerah perantauan maka diperlukan untuk menanam sifat orang Minang seperti huduik baraka - baukue jo bajangko (hidup berpikir - berukur dan berjangka), baso jo basi - malu jo sopan (basa basi - sopan santun), setia, adil, rajin, rendah hati, hormat, cermat, berani, arif, bijaksana, sabar, tenggang rasa dan sebagainya. Hal ini menjadi panutan bagi orang Minang yang menjadi seorang pemimpin di daerah perantauan yang mampu turut andil dalam bermasyarakat di mana pun ia berada.

\section{Simpulan}

Berdasarkan hasil penelitian yang telah dilakukan maka disimpulkan bahwa pantun Minang pada Masyarakat Minangkabau Kota Bengkulu terdapat tanda semiotika yang terkemas di dalamnya yakni dari tanda ikon, indeks, dan simbol. Tanda Ikon lebih sering digunakan pada diksi kata benda dengan penempatannya 
berada di baris pertama dan kedua pantun Minang. Sedangkan tanda indeks ditandai dengan semua aktifitas kehidupan yang mana pada pantun Minang seringkali muncul di baris kedua atau ketiga pantun Minang. Serta tanda simbol memiliki makna tersurat dan tersirat di dalam pantun yang letaknya sering kali berada di isi pantun, atau pada baris ketiga dan keempat pantun Minang. Dengan demikian, semiotika pada pantun Minang terdapat disetiap unsur permainan kata pada diksi pantun Minang Masyarakat Minangkabau Kota Bengkulu.

\section{Daftar Pustaka}

Amir, M.S. 2001. Adat Minangkabau Pola dan Tujuan Hidup Orang Minang. Jakarta: Mutiara Sumber Widya.

Burhan, Bungin. 2010. Analisis Data Penelitian Kualitatif. Jakarta: Raja Grafindo Persada.

Djamaris, Edwar. 2002. Pengatar Sastra Rakyat Minangkabau. Jakarta: Yayasan Obor Indonesia.

Eliya, I. (2018). (The function of Speech Code Choice in Religious Discussion: A Case Study on the Speeches of K. Jalabahasa, 14(1), 1-19. Retrieved from.

http://jurnal.balaibahasajateng.id/index .php/jalabahasa/article/view/145

Endraswara, Suardi. 2008. Metodologi Penelitian Sastra. Yogyakarta: MedPress.
Fang, Liaw Yock. 1993. Sejarah Kesusastraan Melayu Klasik. Jakarta: Erlangga.

Hakimy, Idrus. 1997. Pengangan Penghulu, Bundo Kanduang, dan Pidato Alua Pasambahasan Ada., Bandung: Remaja Rosdakarya.

Hakimy, Idrus. 1997. Pokok-pokok Pengetahuan Adat Alam Minangkabau. Bandung: Remaja Rosdakarya.

Hakimy, Idrus. 1997. Rangkaian Mustika Adat Basandi Syarak di Minangkabau. Bandung: Remaja Rosdakarya.

Hoed, H. Benny. 2011. Semiotik dan Dinamika Sosial budaya. Jakarta: Komunitas Bambu.

Sobur, Alex. 2001. Analisis Teks Media. Bandung: Remaja Rosdakarya.

Sobur, Alex. 2006. Semiotika Komunikasi. Bandung: Remaja Rosdakarya.

Soenaryo, Andi. 2010. Pantun dan Puisi. Jakarta: Kartika.

Yogi, Rivai, A. 1980. Sastra Minang. Jakarta: Mutiara.

Zaimar, Okke K.S. 2008. Semiotik dan Penerapannya dalam Karya Sastra. Jakarta: Pusat Bahasa Departemen Pendidikan Nasional.

Zoest, Aart van. 1991. Fiksi dan Nonfiksi dalam Kajian Semiotik. Jakarta: Intermasa. 